\title{
Modified habitats change ecological processes affecting a non-indigenous epibiont
}

\author{
E. M. Marzinelli ${ }^{1,2, *}$, A. J. Underwood ${ }^{1}{ }^{,}$R. A. Coleman ${ }^{1}$ \\ ${ }^{1}$ Centre for Research on Ecological Impacts of Coastal Cities, School of Biological Sciences, Marine Ecology Laboratories A11, \\ University of Sydney, NSW 2006, Australia \\ ${ }^{2}$ Present address: Centre for Marine Bio-innovation and Sydney Institute of Marine Science, School of Biological, \\ Earth and Environmental Sciences, University of New South Wales, Sydney NSW 2052, Australia
}

\begin{abstract}
Urbanisation of coastal habitats, particularly the increased numbers of pier-pilings, jetties and seawalls along shorelines, affects natural systems. Epibiota on secondary substrata (kelps, Ecklonia radiata) in man-made structures differ from those in natural habitats, but they have received considerably less attention. To understand the consequences of changes in the structure of these assemblages, it is therefore necessary to determine which ecological processes are being affected and the factors influencing them. In Sydney Harbour, kelps on pier-pilings supported greater covers of bryozoans, particularly of the non-indigenous species Membranipora membranacea, than found on natural reefs. Experimental transplants of kelps without epibiota from reefs to pilings showed that recruitment and growth of colonies of $M$. membranacea were much greater on pilings than on reefs. Patterns of distribution and abundance of this epibiotic bryozoan are determined by a combination of these processes and probably influenced by differences in abiotic and biotic characteristics between habitats. Understanding how these components of habitats affect ecological processes is necessary to allow sensible prediction of the effects of modifying habitats on the ecology of organisms.
\end{abstract}

KEY WORDS: Urbanisation $\cdot$ Modification of habitat $\cdot$ Kelp $\cdot$ Epibiota $\cdot$ Bryozoans $\cdot$ Recruitment Growth

\section{INTRODUCTION}

Habitats are being modified by human activities. Besides direct effects of modified habitats, which change abiotic factors, there are potential indirect effects through interactions with other stressors (Sala et al. 2000, Didham et al. 2007). In particular, alterations of environmental factors in modified habitats can facilitate the introduction of species, which, in turn, may act synergistically affecting ecological processes and, consequently, the function of natural systems (Didham et al. 2007). Concerns about increasing rates of anthropogenic disturbances therefore make it necessary to go beyond the study of ecological patterns to investigate the processes that deter- mine them (Pressey et al. 2007). Understanding such processes is crucial to develop successful strategies for management and conservation.

In coastal waters surrounding cities, natural habitats are often replaced by man-made structures, such as marinas, breakwaters and seawalls. These structures provide novel substrata for hard-bottom organisms but have characteristics that make them intrinsically different from natural habitats. For instance, these structures affect hydrodynamic processes, reducing water flow and wave energy (Floerl \& Inglis 2003), usually causing greater sedimentation rates. The presence of piers and wharves also reduces light (Glasby 1999). As a result, the structure of assemblages in these modified habitats differs from those 
on natural substrata (e.g. Connell \& Glasby 1999, Bulleri 2005). For example, many non-indigenous species become established on artificial structures that act as entry points facilitating their spread across other habitats (e.g. Glasby et al. 2007, Dafforn et al. 2009). Recent studies have shown that the addition of these structures also affects epibiota on habitatforming species occurring in these habitats (e.g. macroalgae; Marzinelli et al. 2009).

Stands of kelps provide habitat and other resources (e.g. food) to many species. In Sydney Harbour, the kelp Ecklonia radiata occurs on pier pilings in marinas and on natural rocky reefs. Covers of epibiota on laminae of kelps on pilings are, however, much greater than on kelps on adjacent reefs (Marzinelli et al. 2009). Greater covers of epibiota can have detrimental effects on kelps and, in turn, on the organisms that use kelps as a resource (Wahl \& Hay 1995, Levin et al. 2002, Wahl 2008). For example, greater covers of epibionts can have negative effects on kelps by reducing the area available for photosynthesis (Cancino et al. 1987), which can be enhanced by the reduced levels of light under piers (Hepburn et al. 2006), thereby altering primary productivity. Epibiota can also make kelps more susceptible to drag (D'Antonio 1985); fronds with greater covers of epibionts are more likely to be torn apart by currents and waves (Lambert et al. 1992). This can contribute to the loss of stands of kelps (Steneck et al. 2002, Schiel et al. 2004, Coleman et al. 2008) and subsequent changes in the structure and function of benthic assemblages (Levin et al. 2002). In Sydney, most of the observed difference in covers of epibiota is due to the non-indigenous bryozoan Membranipora membranacea (Hewitt et al. 2004), which can cover 30 to $50 \%$ of the laminae of kelps on pilings, but only covers $~ 5 \%$ of laminae of kelps on reefs (Marzinelli 2009). Greater covers of bryozoans on kelps on pilings appear to be influenced by properties of the primary habitat (pier pilings) and not due to indirect modifications of kelps by the habitat (Marzinelli et al. 2009). The piers supported by the pilings reduce light significantly, and pilings support much smaller abundances of the sea urchin Holopneustes purpurascens, which lives on the canopy of kelps and feeds on its laminae. Manipulative experiments showed that greater shade and smaller numbers of urchins on pilings are the main factors influencing covers of bryozoans (Marzinelli et al. 2011). These factors are likely to affect several ecological processes, such as recruitment and growth of the bryozoans.

The population structure of many species is often determined by recruitment processes (Underwood \&
Fairweather 1989), which encompass the production and fertilization of gametes, dispersal and survival of larvae, and settlement and survival of individuals until census (Underwood 1979, Keough \& Downes 1982, Todd 1998, Keough \& Swearer 2007). Recruitment of marine invertebrates is affected by several factors. For example, shade increases larval settlement because larvae of many marine invertebrates exhibit negative phototaxis (Thorson 1964, Rodriguez et al. 1993). Also, differential mortality of early settlers due to biological disturbance or predation can affect recruitment (Hunt \& Scheibling 1997). Thus, greater shade and smaller post-settlement mortality in pilings (due to low abundances of urchins) could, therefore, increase recruitment of bryozoans to kelps.

Another ecological process that can determine the structure of populations is growth. In assemblages of sessile invertebrates, for instance, growth rates of species often determine the outcome of competitive interactions (Nandakumar \& Tanaka 1994). Also, the feeding performance of many filter-feeders is affected by the size of the colonies (Pratt 2005). Artificial structures affect waves and currents, which might increase availability of food through passive hydrodynamic processes. This, in turn, may lead to greater growth of bryozoans on pilings (Okamura 1992), resulting in greater covers on laminae of kelps.

The aim of this study was therefore to determine the extent to which these 2 ecological processes are being affected by the modified habitat formed by pilings. We examined the models that differences in covers of Membranipora membranacea between kelps on pier pilings and rocky reefs are caused by: (1) greater recruitment to kelps on pilings, (2) faster growth of colonies on kelps on pilings, or (3) a combination of both processes. Because covers of bryozoans are much greater on kelps on pilings (Marzinelli et al. 2009), the space available for recruitment is significantly smaller than on kelps on reefs. Therefore, to provide similar space for recruitment in the 2 habitats, we transplanted kelps from reefs to pilings. By doing this, we avoided possible confounding due to the space available to recruit and other potential sources of confounding, such as presence of greater numbers of conspecifics. This methodology could be employed because we first showed that the pattern of differences in covers of bryozoans was not due to differences in the type of kelps that grow in each habitat (Marzinelli et al. 2009). Model 1 leads to the prediction that numbers of colonies and percentage covers of bryozoans recruiting to laminae of kelps transplanted from reefs to pilings will be greater than 


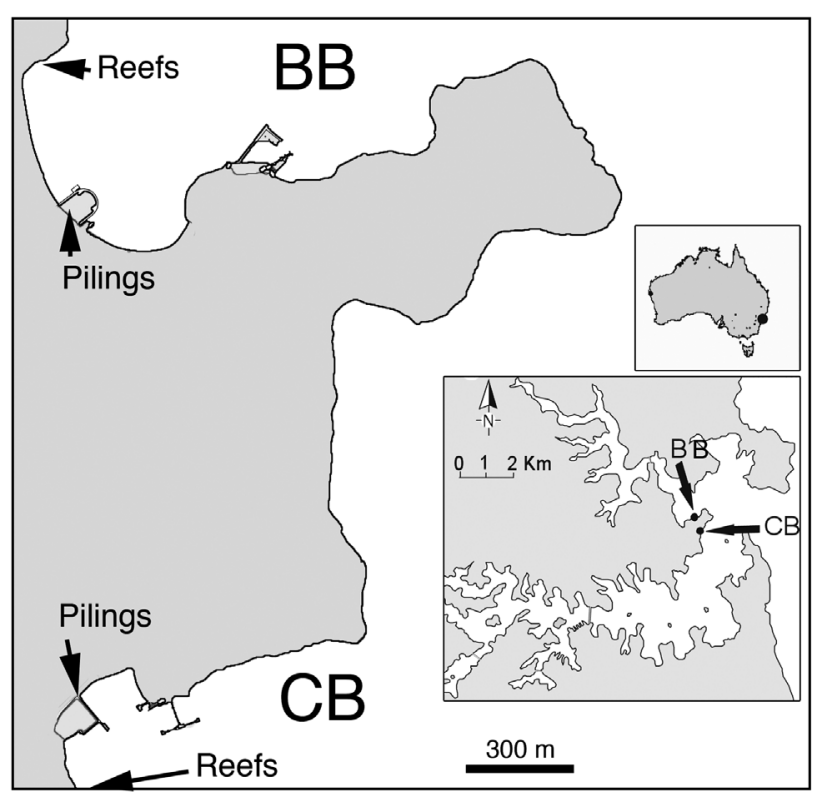

Fig. 1. Pilings and reefs at Chowder Bay (CB) and Balmoral Beach (BB) in Sydney Harbour, Australia

on those on reefs. Model 2 leads to the prediction that growth of colonies of $M$. membranacea will be faster on pilings than on reefs. Finally, model 3 leads to the prediction that recruitment to kelps and growth rates of colonies will be greater on pilings than on reefs. Because each colony of bryozoans is started by a single individual which, after larval settlement and metamorphosis, starts reproducing asexually (by budding), recruitment can be determined as the number of colonies on laminae of kelps. Growth rates of individual colonies of $M$. membranacea were measured on kelps on pilings and on reefs.

\section{MATERIALS AND METHODS}

\section{Recruitment}

Ecklonia radiata without epibiota on their laminae were experimentally transplanted from rocky reefs to pilings at 3 places in Sydney Harbour, Australia (Fig. 1): Chowder Bay $\left(\mathrm{CB}^{3} 33^{\circ} 50^{\prime} \mathrm{S}, 151^{\circ} 15^{\prime} \mathrm{E}\right)$ and 2 sites ( 100 $\mathrm{m}$ apart) at Balmoral Beach $\left(\mathrm{BB}_{;} 33^{\circ} 49^{\prime} \mathrm{S}\right.$, $151^{\circ} 15^{\prime} \mathrm{E}_{\text {; }}$ see Marzinelli et al. 2009). Each location has natural rocky reefs (sandstone platforms) and wharves with wooden pilings and decking built over soft sediments ( $\sim 2$ to $6 \mathrm{~m}$ depth). The distance between reefs and pilings was $\sim 300 \mathrm{~m}$ at each place. Fifteen kelps were collected haphazardly ( $\sim \mathrm{m}$ apart) from reefs at the same depth (1 to $2 \mathrm{~m}$ ) by carefully detaching the holdfast from the substratum. Five individuals from each place were then randomly assigned to each of 3 treatments: (1) individuals Transplanted (TP) to pilings; (2) Disturbed (D) individuals, which were disturbed in the same manner as required for transplantation, but returned to their original site on reefs; (3) Translocated (TL) individuals, which were similarly disturbed, but taken to a different site on reefs. In addition, 5 Undisturbed (U) individuals were marked in situ at each place on reefs. Disturbed and Translocated treatments allowed distinguishing among the possible influences of disturbances due to the procedure involved in the transplantation of kelps or moving the kelps to an unfamiliar place in the same habitat, respectively (Chapman 1986). Transplanted, Disturbed and Translocated kelps were held in place on the reefs or pilings by a transplanting device (Marzinelli et al. 2009). A cable tie was placed around the stipe and 3 cable ties were threaded through the former and cable tied onto a square piece of plastic mesh $\left(361 \mathrm{~cm}^{2}\right)$ placed underneath the holdfast, keeping the kelp in an upright position. On rocky reefs, the mesh was attached to the holdfast of other individuals in the kelp-stand using 3 cable ties. A rope was placed around pilings and the devices were cabletied to this rope. On pilings, 5 kelps from each place were marked in situ and assigned to a fifth treatment, Undisturbed pilings $(\mathrm{P})$, to estimate recruitment to kelps with great covers of epibiota and to control for possible differences in recruitment between kelps transplanted to pilings and those already on pilings. Most of the kelps on pilings had bryozoans on their laminae. On each kelp, 1 secondary lamina without epibiota was marked using cable ties (around the lamina) and assigned to the $\mathrm{P}$ treatment. Comparing recruitment to secondary lamina of undisturbed kelps on pilings with recruitment to the whole thallus of undisturbed kelps on reefs would be confounded because the space available for recruitment (and the numbers and/or covers of conspecifics) differs between the 2 habitats. Thus, to determine differences in recruitment between habitats, recruitment to undisturbed kelps on reefs was compared with recruitment to kelps transplanted from reefs to pilings (and appropriate procedural controls, see above), which have similar covers of bryozoans and space availability (see 'Introduction').

This experiment was performed 3 times to test for consistency over time: 16 October to 22 November 2007, 1 March to 14 April 2008 and 11 December 2008 to 7 January 2009. Experiments lasted for 4 to 6 wk to allow recruitment and growth of epibiota. Longer experiments were not necessary because 
when kelps were transplanted from reefs to pilings and vice versa in previous experiments, percentage covers became similar to that on the opposite habitat after 1 mo (Marzinelli et al. 2009). Each kelp was sampled by taking 5 random photographs of the laminae (covers do not seem to differ among sections or surfaces of laminae at these locations; Marzinelli 2009) with an Olympus 7 megapixel underwater digital camera, which allowed sampling colonies larger than $\sim 0.05 \mathrm{~cm}^{2}$. A frame was mounted to the camera to ensure that each photo was always the same distance from the substratum $(6 \mathrm{~cm})$ and covered the same area $(4 \times 5 \mathrm{~cm})$, which provided the greatest possible resolution and precision. Photographs were analysed on a computer screen; the colonies of bryozoans were counted (including those partially within the quadrat) and the percentage cover estimated, using 30 regularly-spaced points over the entire photograph. Taxa that were in the quadrat but not under these points were assigned an arbitrary cover of $0.5 \%$. Whenever possible, animals were identified to species.

\section{Growth}

A pilot study was done in May 2007 at each of 2 sites on pilings or reefs at BB to test the methodology. Ecklonia radiata with colonies of Membranipora membranacea occupying areas $<16 \mathrm{~cm}^{2}$ were sampled haphazardly every $\sim 3 \mathrm{~m}$ by snorkelling. Ten colonies, each from different individuals of $E$. radiata, were marked in situ by attaching a circular plastic earring ( 0.75 to $1 \mathrm{~cm}$ diameter) to the lamina $\sim 2 \mathrm{~cm}$ from each colony. Tags were also attached to the stipe of each kelp with cable ties. At the start of the experiment and after 1 and $7 \mathrm{~d}$, each colony was photographed as above ('Materials and methods: Recruitment'). Photographs were analysed using the Image-J computer software and the area of each colony was calculated for each time of sampling. A scale bar drawn on the frame was used to calibrate measurements. Sizespecific growth rate per unit time (1 wk) of $M$. membranacea colonies were calculated as $\left(\right.$ area $_{\text {end }}-$ area $_{\text {start }} /\left(\right.$ area $_{\text {start }} \times$ time $)$.

Results of the pilot study indicated that the methodology used produced reliable data on growth, so that hypotheses could be tested. In reefs, $\sim 50 \%$ of the tags were lost. Thus, many colonies sampled at the start could not be identified with reliability after $7 \mathrm{~d}$, so these were not included in the analyses. More colonies were therefore tagged on the later experiments. Because there was no significant variability in growth of bryozoans between sites in each habitat (see Results: Growth), subsequent experiments were conducted at a greater spatial scale (Location; see below).

This experiment was then repeated 3 times: 1 to 8 May, 15 to 22 May, and 19 to 27 December 2008. Colonies of Membranipora membranacea were sampled on kelps on pilings or rocky reefs at $\mathrm{CB}$ and $\mathrm{BB}$. At each location, kelps with $M$. membranacea colonies with an area $<16 \mathrm{~cm}^{2}$ were tagged and sampled as described above. Fifty colonies on kelps on reefs ( $\mathrm{n}=1$ to 2 colonies per kelp) and 25 colonies on kelps on pilings ( $\mathrm{n}=1$ to 3 colonies per kelp) were marked in situ and sampled at the start of the experiments and after $7 \mathrm{~d}$ as described above.

\section{Analyses of data}

Analyses of variance (ANOVA) were used to examine differences among means. When Cochran's test for heterogeneity of variances was significant and no transformation was possible, the analysis of variance was still done because it is robust to departures from the assumptions when sample size is large (Underwood 1981, 1997). Non-significant interactions with p > 0.25 were pooled (Underwood 1997). Where significant interaction terms were detected, StudentNewman-Keuls (SNK) comparisons of means were used to determine which treatments differed (Underwood 1981, 1997). All tests were done using GMAV 5 statistical software for Windows (Underwood \& Chapman 1997). Analyses are explained in detail in each Table.

\section{RESULTS}

\section{Recruitment}

Few species recruited to kelps during the experiments. Membranipora membranacea recruited to kelps on pilings and reefs, representing $>90 \%$ of the colonies in each habitat. Bugula stolonifera recruited to kelps in each habitat, whereas Tubulipora sp. and Disporella novaehollandiae recruited only on reefs.

In 2007, several kelps were lost during the experiment, so only 3 were used in analyses. Recruitment of Membranipora membranacea did not differ among treatments (Fig. 2, Table 1a). In the second site at BB, however, recruitment only occurred on kelps transplanted to pilings (Fig. 2). Total recruitment was greater at CB (Fig. 2, Table 1). Covers of M. membranacea differed among treatments across places 

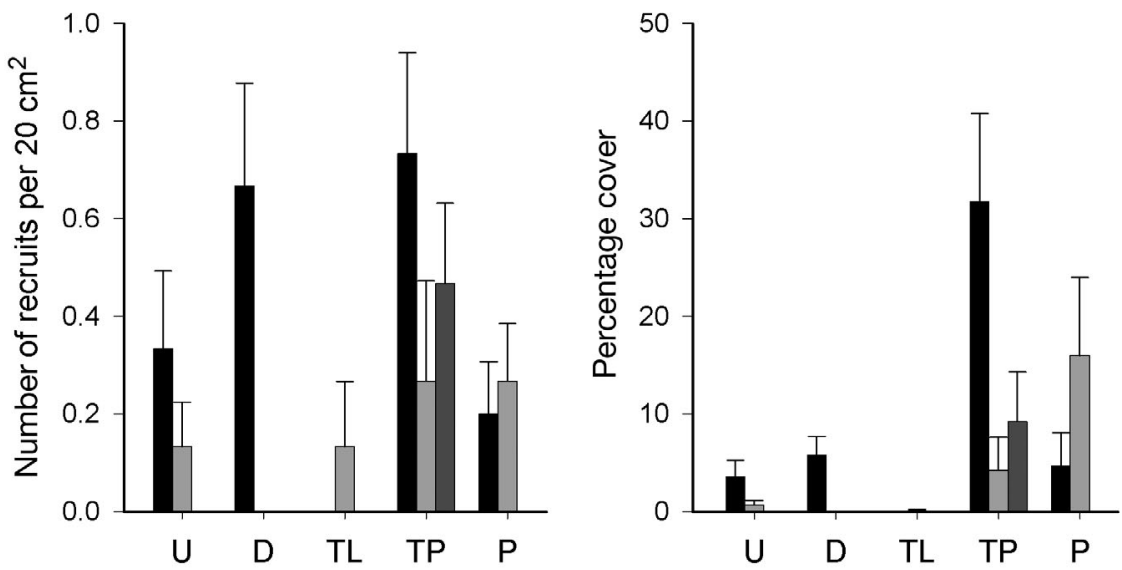

Fig. 2. Membranipora membranacea. Number of recruits per $20 \mathrm{~cm}^{2}$ or percentage cover on kelp laminae $(\mathrm{means}+\mathrm{SE} ; \mathrm{n}=3$ ) 5 wk after transplantation in 2007, at 3 places in Sydney Harbour: CB (black bars), BB - Site 1 (light grey bars) and Site 2 (dark grey bars). Treatments are: Undisturbed reefs (U), Disturbed (D), Translocated (TL), Transplanted to pilings (TP), and Undisturbed pilings (P)

(Table 1b). In CB, covers on kelps transplanted to pilings (TP) were significantly greater than on kelps assigned to any of the other treatments ( $\mathrm{U}, \mathrm{D}, \mathrm{TL}, \mathrm{P}$; Fig. 2). In the first site at $B B$, covers on undisturbed kelps on pilings $(\mathrm{P})$ were significantly greater than in all the other treatments, despite a trend of greater covers on kelps transplanted to pilings (TP) than on undisturbed or controls on reefs (U, D, TL; Fig. 2). In

Table 1. Analyses of (a) number of colonies and (b) percentage cover of bryozoans or Membranipora membranacea on laminae of Ecklonia radiata for each individual kelp after $5 \mathrm{wk}$ in 2007. Treatment (U, D, TL, TP, P) was a fixed factor with 5 levels and Place was random with 3 levels. Kelp was random with 3 levels nested in $\operatorname{Tr} \times \mathrm{Pl}$. The replicates were the quadrats $(\mathrm{n}=5)$. Cochran's test $(C)$ was used to test assumptions of homogeneity of variance. Transformation of data failed to homogenize variances, so no transformation was done. Non-significant interactions $\left({ }^{\mathrm{x}}\right)$ with $\mathrm{p}>0.25$ were pooled. ${ }^{* *} \mathrm{p}<0.01 ;{ }^{*} \mathrm{p}<0.05 ; \mathrm{ns}$ : $\mathrm{p}>0.05$

\begin{tabular}{|c|c|c|c|c|c|c|c|}
\hline \multirow[b]{2}{*}{ Source } & \multicolumn{4}{|c|}{ Bryozoans (total) } & \multicolumn{3}{|c|}{ M. membranacea } \\
\hline & $\mathrm{df}$ & MS & $F$ & $\mathrm{p}$ & MS & $F$ & $\mathrm{p}$ \\
\hline \multicolumn{8}{|c|}{ a) Number of colonies } \\
\hline Treatment Tr & 4 & 1.37 & 2.47 & ns & 1.25 & 2.42 & $\mathrm{~ns}$ \\
\hline Place Pl & 2 & 1.83 & 5.89 & $* *$ & 1.77 & 6.14 & $* *$ \\
\hline $\operatorname{Tr} \times \mathrm{Pl}$ & 8 & 0.55 & 1.78 & ns & 0.52 & 1.79 & ns \\
\hline Kelp $(\operatorname{Tr} \times \mathrm{Pl})$ & 30 & 0.31 & 1.27 & ns & 0.28 & 1.29 & ns \\
\hline \multirow[t]{2}{*}{ Residual } & 180 & 0.24 & & & 0.22 & & \\
\hline & \multicolumn{4}{|c|}{$C=0.16^{* *}$} & \multicolumn{3}{|c|}{$C=0.18^{* *}$} \\
\hline \multicolumn{8}{|c|}{ b) Percentage cover } \\
\hline Treatment Tr & 4 & 1715 & 2.02 & ns & 1710 & 2.00 & ns \\
\hline Place Pl & 2 & 1061 & 5.26 & ${ }^{* *}$ & 1045 & 5.21 & $* *$ \\
\hline $\operatorname{Tr} \times \mathrm{Pl}$ & 8 & 851 & 4.22 & $* *$ & 856 & 4.27 & $* *$ \\
\hline${ }^{x} \operatorname{Kelp}(\operatorname{Tr} \times \mathrm{Pl})$ & 30 & 129 & & & 127 & & \\
\hline \multirow[t]{2}{*}{ Residual } & 180 & 214 & & & 212 & & \\
\hline & & \multicolumn{3}{|c|}{$C=0.22^{* *}$} & \multicolumn{3}{|c|}{$C=0.22^{* *}$} \\
\hline
\end{tabular}

the second site at $\mathrm{BB}$, there were no significant differences among treatments. Recruitment, however, only occurred to kelps transplanted to pilings (TP; Fig. 2).

In 2008 and 2009, only 2 colonies of bryozoans recruited to undisturbed kelps on pilings (P), so this treatment was not included in the analyses. In 2008, there was significantly greater recruitment of Membranipora membranacea to kelps transplanted to pilings (TP) than to undisturbed kelps on reefs (U) or controls (D, TL) at the 2 sites in BB (Fig. 3, Table 2). Covers of $M$. membranacea were significantly greater on kelps transplanted to pilings (TP) than on undisturbed kelps on reefs (U) or controls (D, TL) at CB and the first site in BB (Fig. 3).

In 2009, recruitment of Membranipora membranacea was significantly greater to kelps transplanted to pilings (TP) than to undisturbed kelps on reefs (U) or controls $(\mathrm{D}, \mathrm{TL})$ at the 3 places the experiment was done (Fig. 4; Table 3). The area of colonies that recruited to kelp on pilings or reefs was small $\left(<4 \mathrm{~cm}^{2}\right)$, so percentage cover was not estimated.

\section{Growth}

Growth rates were estimated by calculating the difference between final and initial colony areas and dividing this difference by initial area of each colony. Data were ln-transformed prior to analyses. 

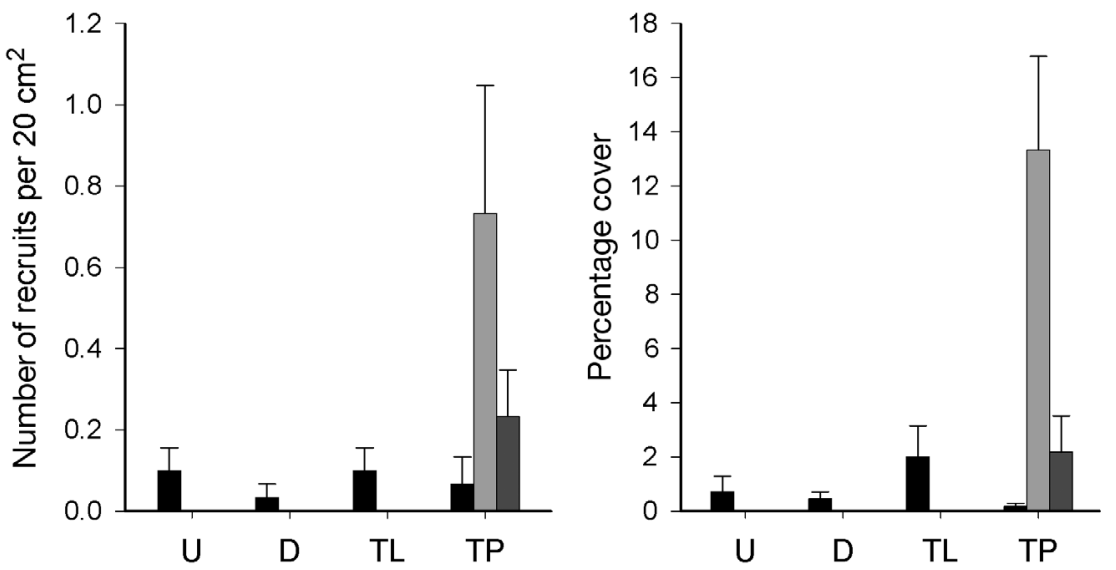

Fig. 3. Membranipora membranacea. Number of recruits per $20 \mathrm{~cm}^{2}$ or percentage cover on kelp laminae $(\mathrm{means}+\mathrm{SE} ; \mathrm{n}=5)$ 5 wk after transplantation in 2008, at 3 places in Sydney Harbour: CB (black bars), BB - Site 1 (light grey bars) and Site 2 (dark grey bars). Treatments are: Undisturbed reefs (U), Disturbed (D), Translocated (TL), and Transplanted to pilings (TP)

In the pilot study at 2 sites in BB in May 2007, growth of Membranipora membranacea after $1 \mathrm{~d}$ was in most cases $<10 \%$ of the growth after $7 \mathrm{~d}$ (Table 4 ). Because the measurements used to estimate measurement error were small $(<10 \%)$, this measurement error was not considered in the other analyses. Growth rates (means $\pm \mathrm{SE}$ ) of $M$. membranacea after $7 \mathrm{~d}$ were greater on kelps on pilings $\left(1.3 \pm 0.2 \mathrm{wk}^{-1}\right)$ than on reefs $\left(0.6 \pm 0.1 \mathrm{wk}^{-1}\right)$. This was consistent across sites (Table 5).

Table 2. Analyses of (a) number of colonies and (b) percentage cover of bryozoans or Membranipora membranacea on laminae of Ecklonia radiata for each individual kelp after $6 \mathrm{wk}$ in 2008. Treatment (U, D, TL, TP) was a fixed factor with 4 levels and Place was a random factor with 3 levels. Kelp was random with 6 levels nested in $\mathrm{Tr} \times \mathrm{Pl}$. The replicates were the quadrats $(\mathrm{n}=5)$. Cochran's test $(C)$ was used to test assumptions of homogeneity. Transformation of data failed to homogenize variances, so no transformation was done. Non-significant interactions $\left({ }^{\mathrm{x}}\right)$ with $p>0.25$ were pooled. ${ }^{* *} \mathrm{p}<0.01 ;{ }^{*} \mathrm{p}<0.05 ; \mathrm{ns}$ : $\mathrm{p}>0.05$

\begin{tabular}{|c|c|c|c|c|c|c|c|}
\hline \multirow[b]{2}{*}{ Source } & \multicolumn{4}{|c|}{ Bryozoans (total) } & \multicolumn{3}{|c|}{ M. membranacea } \\
\hline & df & MS & $F$ & $\mathrm{p}$ & MS & $F$ & $\mathrm{p}$ \\
\hline \multicolumn{8}{|c|}{ a) Number of colonies } \\
\hline Treatment Tr & 3 & 9.91 & 1.85 & ns & 2.29 & 2.10 & ns \\
\hline Place Pl & 2 & 6.34 & 10.80 & ** & 0.55 & 4.98 & ** \\
\hline $\operatorname{Tr} \times \mathrm{Pl}$ & 6 & 5.36 & 9.13 & ** & 1.09 & 9.81 & ** \\
\hline $\operatorname{Kelp}(\operatorname{Tr} \times \mathrm{Pl})$ & 60 & 0.59 & 0.32 & ** & 0.11 & 0.32 & ** \\
\hline \multirow[t]{2}{*}{ Residual } & 288 & 1.83 & & & 0.35 & & \\
\hline & \multicolumn{4}{|c|}{$C=0.55^{* *}$} & \multicolumn{3}{|c|}{$C=0.29^{* *}$} \\
\hline \multicolumn{8}{|c|}{ b) Percentage cover } \\
\hline Treatment Tr & 3 & 1035 & 1.58 & ns & 538 & 1.27 & ns \\
\hline Place Pl & 2 & 597 & 10.81 & ${ }^{* *}$ & 283 & 7.31 & ${ }^{* *}$ \\
\hline $\operatorname{Tr} \times \mathrm{Pl}$ & 6 & 657 & 11.90 & ** & 425 & 10.99 & ** \\
\hline${ }^{\mathrm{x}} \operatorname{Kelp}(\operatorname{Tr} \times \mathrm{Pl})$ & 60 & 55 & & & 39 & & \\
\hline \multirow[t]{2}{*}{ Residual } & 288 & 55 & & & 39 & & \\
\hline & & \multicolumn{3}{|c|}{$C=0.37^{* *}$} & \multicolumn{3}{|c|}{$C=0.28^{* *}$} \\
\hline
\end{tabular}

During the experiments in 2008, 50\% tags were lost. Because there was no significant variability among kelps (ANOVA, $F_{16,20}=1.05, \mathrm{p} \geq 0.45$ ), this factor was not considered in further analyses (i.e. the replicates were the colonies). In each experiment in May 2008, mean growth rate of Membranipora membranacea colonies was significantly greater on kelps on pilings than on those on reefs at BB (Fig. 5, Table 6). On the contrary, at $\mathrm{CB}$, growth rates were significantly greater on reefs than on pilings in the first experiment. No significant differences were found in the second experiment (Fig. 5; Table 6). In December 2008, growth rates were significantly greater on pilings than on reefs at BB and CB (Fig. 5, Table 7).

\section{DISCUSSION}

In this system, pier-pilings affected recruitment and growth (Model 3) of the non-indigenous bryozoan Membranipora membranacea on kelps.

Recruitment, as for many other ecological processes, is very variable in space and time. This variability can influence the structure of populations. For instance, if recruitment is consistently sparse, it can limit populations (see Underwood \& Fairweather 1989). It is also more difficult to make predictions about the effect of disturbances (here, human modification of habitat) when variability is great (Keough \& Swearer 2007). Recruitment to kelps 


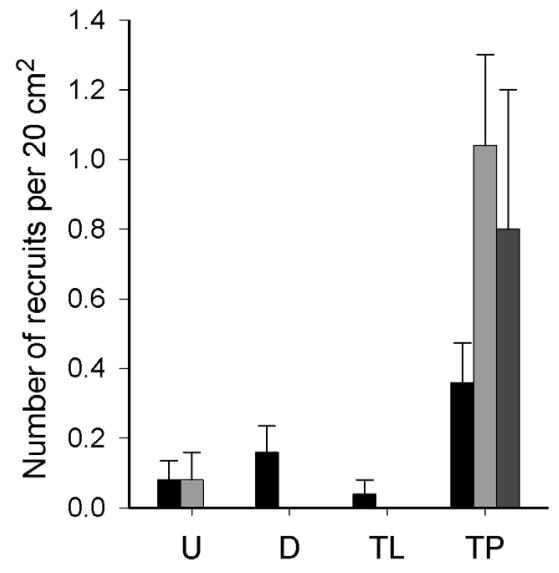

Fig. 4. Membranipora membranacea. Mean (+ SE; $\mathrm{n}=5)$ number of recruits per $20 \mathrm{~cm}^{2}$ on laminae of kelps $5 \mathrm{wk}$ after transplantation in 2009, at 3 places in Sydney Harbour: CB (black bars), BB - Site 1 (light grey bars) and Site 2 (dark grey bars). Treatments are: Undisturbed reefs (U), Disturbed

(D), Translocated (TL), and Transplanted to pilings (TP)

varied among places and times, although, when different, it was always greater on pilings than on reefs. Recruitment of Membranipora membranacea to kelps appears, therefore, to be affected by the pier-pilings.

One of the earliest components of recruitment is the production of larvae. On developed shorelines, the reproductive output of adults can be affected by the structure of the habitat. For example, seawalls sustained smaller limpets than natural rocky shores; limpets on seawalls produced fewer and smaller egg masses than do those on rocky shores (Moreira et al. 2006). Differences in reproductive outputs of bryozoans between pilings and reefs could explain differences in recruitment between these habitats. If, instead, the production of larvae is similar on pilings

Table 3. Analyses of number of colonies of bryozoans or Membranipora membranacea on laminae of Ecklonia radiata for each individual after $4 \mathrm{wk}$ in 2009. Treatment (U, D, TL, TP) was a fixed factor with 4 levels and Place was a random factor with 3 levels. Kelp was random with 5 levels nested in $\operatorname{Tr} \times \mathrm{Pl}$. The replicates were the quadrats $(\mathrm{n}=5)$. Cochran's test $(C)$ was used to test assumptions of homogeneity. Transformation of data failed to homogenize variances, so no transformation was done. ${ }^{* *} \mathrm{p}<0.01$; ${ }^{*} \mathrm{p}<0.05$; ns: $\mathrm{p}>0.05$

\begin{tabular}{|c|c|c|c|c|c|c|c|}
\hline \multirow[b]{2}{*}{ Source } & \multicolumn{4}{|c|}{ Bryozoans (total) } & \multicolumn{3}{|c|}{ M. membranacea } \\
\hline & df & MS & $F$ & $\mathrm{p}$ & MS & $F$ & $\mathrm{p}$ \\
\hline Treatment Tr & 3 & 14.56 & 14.97 & ** & 9.04 & 9.42 & * \\
\hline Place Pl & 2 & 0.24 & 0.20 & ns & 0.37 & 0.36 & ns \\
\hline $\operatorname{Tr} \times \mathrm{Pl}$ & 6 & 0.97 & 0.82 & ns & 0.96 & 0.92 & ns \\
\hline Kelp $(\operatorname{Tr} \times \mathrm{Pl})$ & 48 & 1.19 & 1.93 & $* *$ & 1.04 & 2.38 & $* *$ \\
\hline \multirow[t]{2}{*}{ Residual } & 240 & 0.62 & & & 0.44 & & \\
\hline & \multicolumn{4}{|c|}{$C=0.42^{* *}$} & \multicolumn{3}{|c|}{$C=0.59^{* *}$} \\
\hline
\end{tabular}

Table 4. Membranipora membranacea. Growth rates (means $\pm \mathrm{SE}$ ) on kelp for 2 sites on pilings or rocky reefs after $1(\mathrm{n}=5)$ or $7(\mathrm{n}=4)$ d during the pilot study in May 2007

\begin{tabular}{|lrr|}
\hline & \multicolumn{1}{c}{$1 \mathrm{~d}$} & \multicolumn{1}{c|}{$7 \mathrm{~d}$} \\
\hline Reefs, Site 1 & $0.03 \pm 0.06$ & $0.49 \pm 0.23$ \\
Reefs, Site 2 & $-0.04 \pm 0.03$ & $0.94 \pm 0.40$ \\
Pilings, Site 1 & $0.01 \pm 0.05$ & $3.66 \pm 1.64$ \\
Pilings, Site 2 & $0.11 \pm 0.07$ & $2.70 \pm 0.79$ \\
\hline
\end{tabular}

Table 5. Membranipora membranacea. Analysis of growth rate on kelps on pilings or rocky reefs during the pilot study in May 2007. Habitat (pilings vs rocky reefs) was a fixed factor with 2 levels; Site was a random factor with 2 levels nested in Habitat. The replicates were the colonies $(n=4)$. Because 2 sites ( 1 in pilings and 1 in reefs) had only 3 replicates, the average of these was used as a fourth measure and the df were adjusted accordingly. Cochran's test $(C)$ was used to test assumptions of homogeneity. Data were $\ln (\mathrm{x}+1)$ transformed. ${ }^{* *} \mathrm{p}<0.01 ; \mathrm{ns}$ : $\mathrm{p}>0.05$

\begin{tabular}{|lcccc|}
\hline Source & df & MS & $F$ & $\mathrm{p}$ \\
\hline Habitat Ha & 1 & 2.05 & 249.32 & $* *$ \\
Site (Ha) & 2 & 0.01 & 0.03 & $\mathrm{~ns}$ \\
Residual & 10 & 0.25 & & \\
$C=0.68^{\text {ns }}$ & & & & \\
\hline
\end{tabular}

and reefs, differences in recruitment could be explained by the arrival of propagules (Sousa 1984, Keough 1986, Underwood \& Fairweather 1989). Arrival of propagules to a patch can be influenced by the distance between the source of propagules (i.e. adult individuals producing larvae) and the patch (e.g. Sousa 1984). Distances from potential suppliers of larvae may be smaller for pilings than for reefs, possibly because of greater covers of bryozoans and smaller variability in covers among kelps on pilings (Marzinelli et al. 2009). These 2 models seem, however, unlikely to explain differences in recruitment between pilings and reefs because these habitats are in close proximity ( 300 $\mathrm{m}$ apart).

Larvae disperse through the water column where they can be affected by many factors. Predation, for example, can significantly reduce the numbers of larvae (Thorson 1950). Also, waves and currents affect dispersal of larvae. These physical factors not only influence the numbers of propagules arriving to a patch, but also their survival after settlement. The longer larvae spend swimming, the less selective they become in their responses to settle- 
Table 6. Membranipora membranacea. Analysis of growth rate on kelps on pilings or rocky reefs during both experiments in May 2008. Habitat (pilings vs. rocky reefs) was a fixed factor with 2 levels; Location was a random factor with 2 levels. The replicates were the colonies ( 1 to 8 May, $\mathrm{n}=19 ; 15-22$ May, $\mathrm{n}=17$ ). Cochran's test $(C)$ was used to test assumptions of homogeneity. Data were $\ln (x+1)$ transformed. ${ }^{* *} \mathrm{p}<0.01 ;{ }^{*} \mathrm{p}<0.05 ;$ ns: $\mathrm{p}>0.05$

\begin{tabular}{|c|c|c|c|c|c|c|c|c|}
\hline \multirow[b]{2}{*}{ Source } & \multicolumn{4}{|c|}{1 to $8 \mathrm{May}-$} & \multicolumn{4}{|c|}{-15 to 22 May } \\
\hline & $\mathrm{df}$ & MS & $F$ & $\mathrm{p}$ & $\mathrm{df}$ & MS & $F$ & $\mathrm{p}$ \\
\hline Habitat Ha & 1 & 0.13 & 0.02 & ns & 1 & 0.03 & 0 & ns \\
\hline Location Lo & 1 & 7.46 & 10.51 & ** & 1 & 3.30 & 5.13 & * \\
\hline $\mathrm{Ha} \times \mathrm{Lo}$ & 1 & 6.88 & 9.71 & ** & 1 & 7.36 & 11.45 & $* *$ \\
\hline \multirow{2}{*}{ Residual } & 72 & 0.71 & & & 64 & 0.64 & & \\
\hline & \multicolumn{4}{|c|}{$C=0.36^{\mathrm{ns}}$} & & \multicolumn{3}{|c|}{$C=0.62^{* *}$} \\
\hline
\end{tabular}

ment cues (e.g. Marshall \& Keough 2003). This, in turn, may lead to settlement in unsuitable places, e.g. where there is less food or greater predation. Also, greater swimming time can reduce the quality of the larvae, thereby affecting their survival as adults (Marshall et al. 2003).

After larvae arrive at a patch, their settlement can be triggered by physical and/or chemical cues. One of these cues is intensity of light (Thorson 1964). Larvae may also respond to other physical factors, e.g. water-flow (Rodriguez et al. 1993). Chemical cues produced by conspecifics may also trigger settlement (Keough 1984, Raimondi 1988). Cues provided by the pilings or by greater numbers of adult colonies of bryozoans on kelps on pilings could, therefore, influence recruitment to this habitat. The effect of these cues might, however, vary among species (Todd \& Keough 1994) and even among individuals of the same species (Raimondi \& Keough 1990).

Because initial settlement and recruitment were not distinguished, there could have been equal settlement in the 2 habitats, but greater survival of the settlers on kelps on pilings, perhaps due to increased food. Alternatively, post-settlement mortality could have been greater in reefs due to predation (Hunt \& Scheibling 1997). For example, predation of new settlers by fish affected the distribution and abundances of bryozoans (Keough \& Downes 1982). Other studies have also shown the effect of post-settlement predation or disturbance of other organisms (e.g. Osman \& Whitlatch 2004, but see Sams \& Keough 2007 for example of weak effects). Urchins may affect settlers of bryozoans on kelp on reefs through these processes.

Recruitment to undisturbed kelps on pilings was often lower than to transplanted kelps from reefs. This could be explained by differences in the availability of space to settle on kelps in these 2 treatments. The area of a secondary lamina is on average
$1 / 10$ of the area of the whole frond (Wernberg et al. 2003). Only recruitment to a secondary lamina was recorded for undisturbed kelps on pilings because they were already fouled with bryozoans, whereas recruitment was recorded for the whole frond of transplanted kelps.

Similar differences in recruitment between pilings and reefs were found when recruitment was estimated as percentage covers, although the difference between habitats became greater. This indicates that, after settlement, the growth rates of colonies may have been greater on pilings than on reefs. Several models may explain the observed differences in growth-rates between pilings and reefs. For example, increased food on pilings because of differences in water flow in comparison to reefs may cause differences in growth (Okamura 1992, but see Okamura \& Partridge 1999). Also, the presence of neighbour bryozoans could have caused reduced growth on reefs. For example, bryozoans growing close to neighbours grew more slowly than did corresponding isolated colonies (Nandakumar \& Tanaka 1994, Okamura \& Partridge 1999). This model is, however, unlikely to explain slower growth on reefs because very small numbers of bryozoans occur on kelp in this habitat (Marzinelli et al. 2009) and because none of the colonies measured came in contact with other colonies.

At $\mathrm{CB}$, differences in growth between habitats were variable. Growth was faster on pilings at one time, faster on reefs at another time, or did not differ. A possible explanation for this could be great variability in food supply between habitats (Okamura 1992). Alternatively, growth may have been slower due to the presence of neighbours, although this is unlikely because none of the colonies measured came in contact with other colonies. Several studies have, however, shown that growth is very variable in time and space (e.g. Keough 1986, O'Dea \& Okamura 2000), pointing out the necessity of replication (Keough 1986). Although this experiment was done at 2 locations and 3 times, this may be insufficient to test for consistency in the observed patterns.

Further research should focus on studying the link between growth and recruitment of Membranipora membranacea. Faster growth of bryozoans leads to larger colonies, which may survive better than small ones. This, in turn, may affect the production of larvae because larger colonies have more zooids, each 


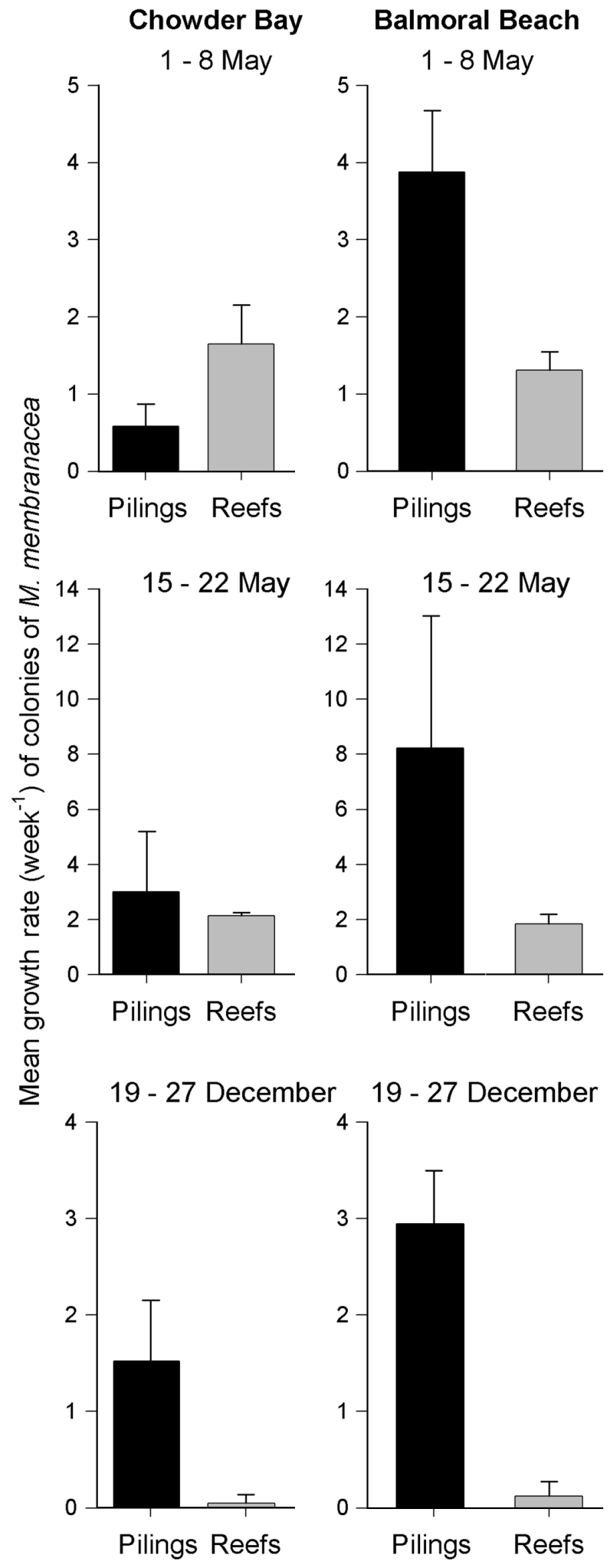

Fig. 5. Membranipora membranacea. Mean (+ SE) growth rates $\left(\mathrm{wk}^{-1}\right)$ of colonies on kelps on pilings (black bars) or reefs (grey bars) during the first $(n=19)$, second $(n=17)$ and third $(\mathrm{n}=15)$ experiment at Chowder Bay and Balmoral Beach
Table 7. Membranipora membranacea. Analysis of growth rate on kelp on pilings or rocky reefs during the experiment in December 2008. Habitat (pilings vs rocky reefs) was a fixed factor with 2 levels; Location was a random factor with 2 levels. The replicates were the colonies $(n=15)$. Cochran's test $(C)$ was used to test assumptions of homogeneity. Data were $\ln (\mathrm{x}+1)$ transformed. SNK tests of means were done where there were interactions: ${ }^{*} \mathrm{p}<0.05 ; \mathrm{ns}$ : $\mathrm{p}>0.05$

\begin{tabular}{lcccc|}
\hline Source & df & MS & $F$ & $\mathrm{p}$ \\
\hline Habitat Ha & 1 & 12.20 & 7.77 & $\mathrm{~ns}$ \\
Location Lo & 1 & 1.59 & 3.97 & $*$ \\
Ha x Lo & 1 & 1.57 & 3.91 & $*$ \\
Residual & 56 & 0.40 & & \\
$\quad C=0.48^{*}$ & & & & \\
SNK: Chowder Bay, Pilings > Reefs; Balmoral Beach, & \\
Pilings > Reefs & & & \\
\end{tabular}

one of which is capable of producing larvae (Yoshioka 1982). If the reproductive output of individual zooids in larger colonies is similar to those in smaller ones, larger colonies can release greater numbers of larvae into the water column because they have more zooids (Yoshioka 1982). This could facilitate the dispersal and establishment of this non-indigenous species elsewhere.

This information can be used to minimise the impacts of the replacement of natural habitats by artificial structures. For instance, trying to eliminate non-indigenous epibiota such as Membranipora membranacea to reduce negative effects on kelps and other organisms that inhabit them (Cancino et al. 1987, Wahl \& Hay 1995) will prove to be costly and ineffective because their recruitment and growth are enhanced by the artificial structures, and these processes alone can produce rapid and significant increases in epibiont cover. Also, these non-indigenous species are already established on natural reefs. So, designing artificial structures that mimic natural reefs may be the most effective strategy for management. This is particularly relevant for Sydney Harbour, where natural rocky shores are being replaced by artificial structures, such as seawalls. Altering the design of seawalls to resemble natural shores had proved to successfully enhance diversity (Chapman $\&$ Blockley 2009). Several physical and biological properties of pilings may explain differences between habitats in recruitment of bryozoans to kelps (see Introduction). Of the factors shown to affect bryozoans on kelps in this system (Marzinelli et al. 2011), shade is likely to affect settlement of larvae because they often respond to reduced amounts of light (Thorson 1964, Rodriguez et al. 1993). For example, experimental shading of primary substra- 
tum increased recruitment of bryozoans to pilings (Glasby 1999) and other substrata (Ryland 1960). Conversely, greater densities of sea urchins may reduce settlement of larvae in reefs by enfolding the fronds for attachment or increase post-settlement mortality by grazing on the kelps (Wahl \& Hay 1995). Reducing the shade caused by piers and transplanting urchins to pilings may thus minimize the changes in biodiversity caused by pilings (Marzinelli et al. 2011).

Patterns of biodiversity are generated and maintained by dynamic ecological processes. Human activities are rapidly altering natural habitats and disrupting natural processes, having important consequences on biodiversity (Vitousek et al. 1997). Conservation planning that ignores anthropogenic influences on ecological processes cannot successfully promote the persistence of biodiversity (Pressey et al. 2007). It is therefore necessary to increase our understanding of the effects of modified habitats on ecological patterns and processes to provide information and practical advice for conservation and management. Artificial structures are replacing natural habitats along urbanized shorelines globally. Altering the design of built structures to be better mimics of natural habitats will contribute to the conservation of local biodiversity by preserving natural patterns of abundances and distribution of organisms and the processes that determine them. Further, this can mitigate other potential adverse effects of anthropogenic modification of habitats, e.g. by reducing the 'invasibility' of natural systems and increasing their resilience and stability.

Acknowledgements. This work was supported by funds from an Endeavour International Postgraduate Research Scholarship (to E.M.M.) and grants from the Australian Research Council's Special Research Centres Program (to A.J.U. and R.A.C.). We thank G. Cocco, M.G. Matias and M. Mayer-Pinto for assistance in the field and M. Mayer-Pinto, M. G. Chapman, D. J. Blockley and R. J. Murphy for their helpful comments.

\section{LITERATURE CITED}

Bulleri F (2005) The introduction of artificial structures on marine soft- and hard-bottoms: ecological implications of epibiota. Environ Conserv 32:101-102

> Cancino JM, Munoz J, Munoz M, Orellana MC (1987) Effects of the bryozoan Membranipora tuberculata (Bosc) on the photosynthesis and growth of Gelidium rex Santelices et Abbott. J Exp Mar Biol Ecol 113:105-112

Chapman MG (1986) Assessment of some controls in experimental transplants of intertidal gastropods. J Exp Mar Biol Ecol 103:181-201

Chapman MG, Blockley DJ (2009) Engineering novel habi- tats on urban infrastructure to increase intertidal biodiversity. Oecologia 161:625-635

Coleman MA, Kelaher BP, Steinberg PD, Millar AJK (2008) Absence of a large brown macroalga on urbanized rocky reefs around Sydney, Australia, and evidence for historical decline. J Phycol 44:897-901

$>$ Connell SD, Glasby TM (1999) Do urban structures influence local abundance and diversity of subtidal epibiota? A case study from Sydney Harbour, Australia. Mar Environ Res 47:373-387

D'Antonio C (1985) Epiphytes on the rocky intertidal red alga Rhodomela larix (Turner) C. Agardh: negative effects on the host and food for herbivores? J Exp Mar Biol Ecol 86:197-218

> Dafforn KA, Johnston EL, Glasby TM (2009) Shallow moving structures promote marine invader dominance. Biofouling 25:277-287

Didham RK, Tylianakis JM, Gernmell NJ, Rand TA, Ewers RM (2007) Interactive effects of habitat modification and species invasion on native species decline. Trends Ecol Evol 22:489-496

Floerl O, Inglis GJ (2003) Boat harbour design can exacerbate hull fouling. Austral Ecol 28:116-127

Glasby TM (1999) Effects of shading on subtidal epibiotic assemblages. J Exp Mar Biol Ecol 234:275-290

- Glasby TM, Connell SD, Holloway MG, Hewitt CL (2007) Nonindigenous biota on artificial structures: could habitat creation facilitate biological invasions? Mar Biol 151: 887-895

$>$ Hepburn CD, Hurd CL, Frew RD (2006) Colony structure and seasonal differences in light and nitrogen modify the impact of sessile epifauna on the giant kelp Macrocystis pyrifera (L.) C Agardh. Hydrobiologia 560:373-384

- Hewitt CL, Campbell ML, Thresher RE, Martin RB and others (2004) Introduced and cryptogenic species in Port Phillip Bay, Victoria, Australia. Mar Biol 144:183-202

> Hunt HL, Scheibling RE (1997) Role of early post-settlement mortality in recruitment of benthic marine invertebrates. Mar Ecol Prog Ser 155:269-301

> Keough MJ (1984) Kin-recognition and the spatial distribution of larvae of the bryozoan Bugula neritina. Evolution 38:142-147

Keough MJ (1986) The distribution of a bryozoan on seagrass blades: settlement, growth and mortality. Ecology 67:846-857

Keough MJ, Downes BJ (1982) Recruitment of marine invertebrates: the role of active larval choices and early mortality. Oecologia 54:348-352

Keough MJ, Swearer SE (2007) Early life histories of marine invertebrate and fishes. In: Connell SD, Gillanders BM (eds) Mar Ecology. Oxford University Press, Oxford, p $17-46$

$>$ Lambert WJ, Levin PS, Berman J (1992) Changes in the structure of a New England (USA) kelp bed: the effects of an introduced species. Mar Ecol Prog Ser 88:303-307

$>$ Levin PS, Coyer JA, Petrik R, Good TP (2002) Communitywide effects of nonindigenous species on temperate rocky reefs. Ecology 83:3182-3193

Marshall DJ, Keough MJ (2003) Variation in the dispersal potential of non-feeding invertebrate larvae: the desperate larva hypothesis and larval size. Mar Ecol Prog Ser 255:145-153

> Marshall DJ, Bolton TF, Keough MJ (2003) Offspring size affects the post-metamorphic performance of a colonial marine invertebrate. Ecology 84:3131-3137 
Marzinelli EM (2009) Effects of modification of habitat on kelp epifauna. PhD thesis. University of Sydney

- Marzinelli EM, Zagal CJ, Chapman MG, Underwood AJ (2009) Do modified habitats have direct or indirect effects on epifauna? Ecology 90:2948-2955

Marzinelli EM, Underwood AJ, Coleman RA (2011) Modified habitats influence kelp epibiota via direct and indirect effects. PLoS ONE 6:e21936

Moreira J, Chapman MG, Underwood AJ (2006) Seawalls do not sustain viable populations of limpets. Mar Ecol Prog Ser 322:179-188

Nandakumar K, Tanaka M (1994) Effects of neighboring organisms on the growth of 3 intertidal encrusting cheilostome bryozoans. Mar Ecol Prog Ser 114:157-163

O'Dea A, Okamura B (2000) Life history and environmental inference through retrospective morphometric analysis of bryozoans: a preliminary study. J Mar Biol Assoc UK 80:1127-1128

Okamura B (1992) Microhabitat variation and patterns of colony growth and feeding in a marine bryozoan. Ecology 73:1502-1513

> Okamura B, Partridge JC (1999) Suspension feeding adaptations to extreme flow environments in a marine bryozoan. Biol Bull 196:205-215

Osman RW, Whitlatch RB (2004) The control of the development of a marine benthic community by predation on recruits. J Exp Mar Biol Ecol 311:117-145

> Pratt MC (2005) Consequences of coloniality: influence of colony form and size on feeding success in the bryozoan Membranipora membranacea. Mar Ecol Prog Ser 303: 153-165

Pressey RL, Cabeza M, Watts ME, Cowling RM, Wilson KA (2007) Conservation planning in a changing world. Trends Ecol Evol 22:583-592

Raimondi PT (1988) Settlement cues and determination of the vertical limit of an intertidal barnacle. Ecology 69: 400-407

Raimondi PT, Keough MJ (1990) Behavioral variability in marine larvae. Aust J Ecol 15:427-437

Rodriguez SR, Ojeda FP, Inestrosa NC (1993) Settlement of benthic marine invertebrates. Mar Ecol Prog Ser 97: 193-207

Ryland JS (1960) Experiments on the influence of light on the behaviour of polyzoan larvae. J Exp Biol 37:783-800

Sala OE, Chapin FS III, Armesto JJ, Berlow E and others (2000) Global biodiversity scenarions for the year 2100. Science 287:1770-1774

Sams MA, Keough MJ (2007) Predation during early postsettlement varies in importance for shaping marine sessile communities. Mar Ecol Prog Ser 348:85-101

Editorial responsibility: Lisandro Benedetti-Cecchi, Pisa, Italy
Schiel DR, Steinbeck JR, Foster MS (2004) Ten years of induced ocean warming causes comprehensive changes in marine benthic communities. Ecology 85:1833-1839

Sousa WP (1984) Intertidal mosaics: patch size, propagule availability, and spatially-variable patterns of succession. Ecology 65:1918-1935

Steneck RS, Graham MH, Bourque BJ, Corbett D, Erlandson JM, Estes JA, Tegner MJ (2002) Kelp forest ecosystems: biodiversity, stability, resilience and future. Environ Conserv 29:436-459

Thorson G (1950) Reproductive and larval ecology of marine bottom invertebrates. Biol Rev Camb Philos Soc 25:1-45

Thorson G (1964) Light as an ecological factor in the dispersal and settlement of larvae of marine bottom invertebrates. Ophelia 1:167-208

Todd CD (1998) Larval supply and recruitment of benthic invertebrates: Do larvae always disperse as much as we believe? Hydrobiologia 375/376:1-21

Todd CD, Keough MJ (1994) Larval settlement in hard substratum epifaunal assemblages: a manipulative field study of the effects of substratum filming and the presence of incumbents. J Exp Mar Biol Ecol 181:159-187

> Underwood AJ (1979) The ecology of intertidal gastropods. Adv Mar Biol 16:111-210

Underwood AJ (1981) Techniques of analysis of variance in experimental marine biology and ecology. Oceanogr Mar Biol Annu Rev 19:513-605

Underwood AJ (1997) Experiments in ecology. Their logical design and interpretation using analysis of variance. Cambridge University Press, Cambridge

Underwood AJ, Chapman MG (1997) GMAV 5 for Windows, University of Sydney, Sydney

> Underwood AJ, Fairweather PG (1989) Supply-side ecology and benthic marine assamblages. Trends Ecol Evol 4:16-20

> Vitousek PM, Mooney HA, Lubchenco J, Melillo JM (1997) Human domination of earth's ecosystems. Science 277 : 494-499

Wahl M (2008) Ecological lever and interface ecology: epibiosis modulates the interactions between host and environment. Biofouling 24:427-438

Wahl M, Hay ME (1995) Associational resistance and shared doom - effects of epibiosis on herbivory. Oecologia 102: 329-340

Wernberg T, Coleman M, Fairhead A, Miller S, Thomsen M (2003) Morphology of Ecklonia radiata (Phaeophyta: Laminarales) along its geographic distribution in southwestern Australia and Australasia. Mar Biol 143:47-55

> Yoshioka PM (1982) Role of planktonic and benthic factors in the population dynamics of the bryozoan Membranipora membranacea. Ecology 63:457-468

Submitted: February 22, 2011; Accepted: October 28, 2011 Proofs received from author(s): January 19, 2012 